\title{
Analisis Manfaat Sistem Informasi Penerimaan Mahasiswa Baru dengan Metode IT Balanced Scorecard
}

\author{
Flourensia Sapty Rahayu ${ }^{1}$, Rangga Deputra Ginantaka ${ }^{2}$, Y. Sigit Purnomo WP. ${ }^{3}$ \\ ${ }^{1}$ Prodi Sistem Informasi, Universitas Atma Jaya Yogyakarta \\ Jl. Babarsari 43, Yogyakarta \\ sapty@mail.uajy.ac.id \\ ${ }^{2,3}$ Prodi Teknik Informatika, Universitas Atma Jaya Yogyakarta \\ Jl. Babarsari 43, Yogyakarta \\ rangga.deputra@gmail.com, sigit@mail.uajy.ac.id
}

\begin{abstract}
Student admission is an initial business process anually held by university to get new students. Many universities have implemented Information Technology (IT) to support the process. Atma Jaya University Yogyakarta has also been using IS/IT to run the admission process. Although hopefully will provide many benefits to organization but the formal benefit assessment has never been done yet. This study aims to analyze the benefits of admission information systems using IT Balanced Scorecard (IT BSC). The research was conducted in several stages: data collection, data analysis, and conclusion. Data collection has done by questionnaires, interviews, and direct observation. The results show that the admission information systems has not been fully feasible to support the organization development. Of the four IT BSC perspectives that are measured, benefits can only be perceived in Corporate Contribution perspective, whilst not perceived in the other three perspectives.
\end{abstract}

Keywords: Benefit Analysis, Information System for Student Admission, IT Balanced Scorecard

Intisari-Proses bisnis Penerimaan Mahasiswa Baru (PMB) merupakan proses bisnis awal yang selalu dilakukan setiap tahun oleh universitas untuk mendapatkan mahasiswa baru. Banyak universitas telah memanfaatkan Teknologi Informasi (TI) untuk mendukung proses tersebut. Universitas Atma Jaya Yogyakarta juga telah menggunakan SI/TI untuk menjalankan proses PMB. Meskipun dinilai akan banyak memberikan manfaat namun belum pernah dilakukan penilaian secara formal tentang manfaat dari sistem PMB berbasis TI tersebut. Penelitian ini bertujuan untuk menganalisis manfaat dari sistem informasi PMB dengan menggunakan metode IT Balanced Scorecard (IT BSC). Penelitian dilakukan dalam beberapa tahap yaitu tahap pengumpulan data, analisis data, dan penarikan kesimpulan. Proses pengumpulan data dilakukan dengan teknik kuesioner, wawancara, dan observasi langsung. Hasil penelitian menunjukkan bahwa sistem informasi PMB UAJY belum sepenuhnya dapat dirasakan manfaatnya untuk mendukung organisasi. Dari keempat perspektif IT BSC yang diukur kinerjanya, manfaat baru dapat dirasakan pada perspektif Corporate Contribution sedangkan pada ketiga perspektif yang lain belum dapat dirasakan manfaatnya.

Kata Kunci : Analisis Manfaat, Sistem Informasi Penerimaan Mahasiswa Baru, IT Balanced Scorecard

\section{Pendahuluan}

Proses bisnis Penerimaan Mahasiswa Baru (PMB) merupakan proses bisnis awal yang selalu dilakukan setiap tahun oleh universitas untuk mendapatkan mahasiswa baru. Banyak universitas telah memanfaatkan Teknologi Informasi (TI) untuk mendukung proses tersebut. Pada umumnya Teknologi Informasi yang digunakan untuk proses PMB adalah sistem pendaftaran online. Dengan menggunakan teknologi informasi diharapkan proses dari pendaftaran akan berjalan lancar dan lebih efisien.

Universitas Atma Jaya Yogyakarta (UAJY) sebagai salah satu universitas yang memiliki reputasi tinggi juga telah menggunakan sistem informasi untuk mendukung proses penerimaan mahasiswa baru. Dari awal proses pendaftaran mahasiswa hingga pengumuman hasil telah menggunakan sarana TI. Pengelolaan data-data administratif untuk calon mahasiswa baru juga telah menggunakan aplikasi.

Sistem informasi yang digunakan UAJY untuk proses pendaftaran mahasiswa baru adalah sistem MISSION, sistem PMB Online, sistem CBT, dan InfoPMB Online. Sistem MISSION adalah sistem yang digunakan untuk menyimpan data-data dari berkas calon mahasiswa kedalam basisdata dan juga digunakan untuk penentuan calon mahasiswa. Sistem ini digunakan oleh bagian Kantor Admisi dan Akademik (KAA) untuk mengelola data-data calon mahasiswa baru dan digunakan oleh Koordinator Instrumen Tes dan Evaluasi UAJY untuk mengeksekusi data-data mahasiswa yang diterima. Gambar 1 menunjukkan antarmuka sistem MISSION. 


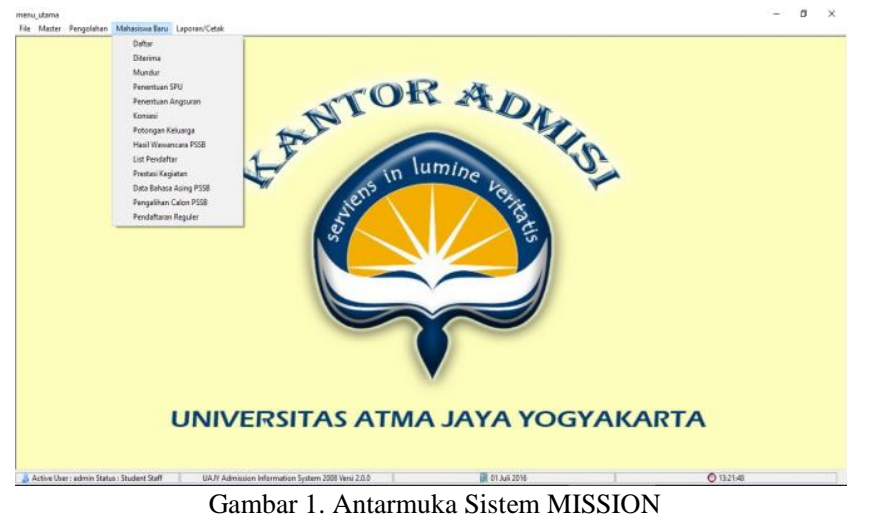

Sistem PMB Online adalah sistem online yang digunakan untuk pendaftaran mahasiswa baru jalur Reguler. Selain langsung datang ke kampus UAJY, calon mahasiswa juga dapat melakukan pendaftaran secara online lewat sistem ini. Pengumuman hasil seleksi seluruh program bisa dilihat di sistem ini. Dengan menggunakan sistem ini kemungkinan kesalahan input data yang mungkin dilakukan oleh petugas pendaftaran dapat diminimalkan. Gambar 2 menunjukkan antarmuka sistem PMB Online.

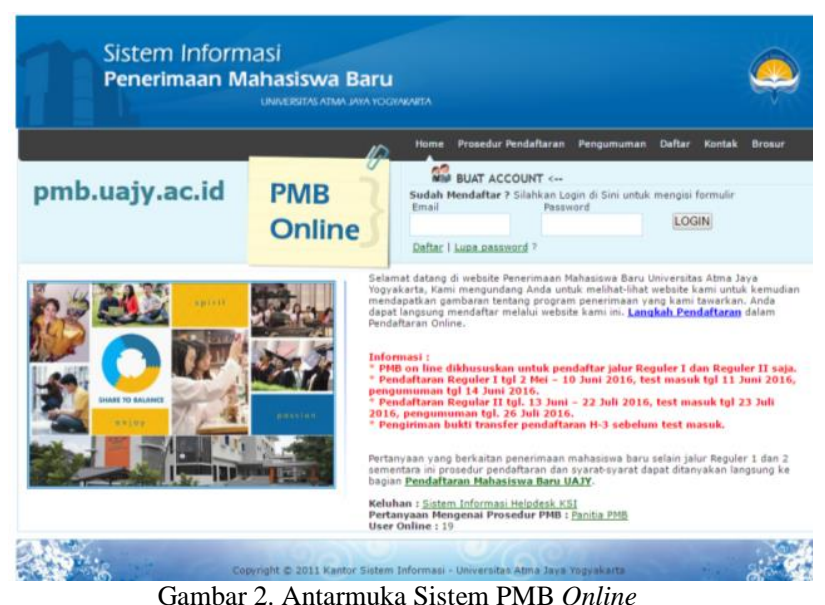

Sistem CBT (Computer Based Test) digunakan sebagai sarana untuk tes online calon mahasiswa baru yang digunakan di jalur Antara. Jalur Antara merupakan program penerimaan mahasiswa baru dengan seleksi ujian tertulis. Tes dilakukan sebelum pengumuman kelulusan SMA/ SMK dan dapat dilakukan di sekolah yang ditunjuk atau di UAJY setiap hari. Calon mahasiswa dapat langsung datang ke kampus UAJY dan melakukan tes sesuai dengan jadual yang tersedia. Tes online ini setara dengan tes tertulis di jalur Reguler namun perbedaannya hasil tes dapat langsung dilihat setelah calon mahasiswa selesai mengerjakan soal. Dengan sistem ini mahasiswa dapat langsung mengetahui apakah dirinya diterima atau tidak. Sebelum menggunakan aplikasi ini mahasiswa butuh waktu berminggu-minggu untuk mengetahui hasil tesnya.

InfoPMB Online adalah sistem yang digunakan untuk level manajemen (rektorat, dekanat, kaprodi, dan kepala unit) untuk memantau perkembangan jumlah calon mahasiwa baru. Dari sistem ini dapat dipantau jumlah pendaftar, jumlah mahasiswa diterima, dan jumlah mahasiswa yang registrasi.
Pengunaan TI untuk proses PMB dianggap memberikan banyak manfaat, namun demikian belum pernah dilakukan penelitian secara formal tentang manfaat yang diperoleh. Berdasarkan permasalahan tersebut penelitian ini dilakukan. Penelitian ini bertujuan untuk mengukur penerapan Sistem Informasi PMB untuk mendukung proses PMB di UAJY dan mengevaluasi manfaat penerapan SI/TI tersebut dengan menggunakan metode Information Technology Balanced Scorecard (IT BSC). Sistem Informasi PMB yang akan dibahas disini mencakup dua aplikasi yaitu sistem PMB online dan sistem MISSION. Sistem PMB online digunakan calon mahasiswa untuk melakukan pendaftaran secara online. Sistem MISSION merupakan sistem administrasi PMB yang digunakan oleh pihak internal UAJY.

\section{TINJAUAN PUSTAKA}

Konsep Balanced Scorecard (BSC) diperkenalkan oleh Kaplan and Norton [1] untuk digunakan pada level enterprise. Premis dasar yang digunakan adalah bahwa evaluasi sebuah perusahaan tidak hanya terbatas pada evaluasi finansial saja tapi juga harus dilengkapi dengan pengukuran yang berkaitan dengan kepuasan konsumen, proses internal, dan kemampuan untuk berinovasi. Hasil yang dicapai pada perspektif-perspektif tambahan ini harus berdampak pada hasil finansial dan mendorong organisasi untuk mencapai tujuan strategisnya dengan menyakinkan bahwa keempat perspektif yang digunakan seimbang.

Beberapa penelitian menerapkan $B S C$ sebagai alat ukur kinerja. Rabbani et al [2] merancang scorecard sebagai alat ukur manajemen kinerja di sebuah rumah sakit. Michalska [3] meneliti penggunaan $B S C$ untuk mengukur keefektifan perusahaan secara menyeluruh di sebuah industri metalurgi di Polandia. BSC dapat juga diterapkan pada TI seperti yang digambarkan oleh Gold [4] dan Willcocks [5]. Asosheh et al [6] menggunakan BSC sebagai framework komprehensif untuk menentukan kriteria evaluasi projek-projek TI. Chand et al [7] membuat framework berbasis $B S C$ untuk menilai kontribusi strategis dari sistem ERP yang diterapkan di perusahaan manufaktur mesin pesawat terbang internasional. Chang et al [8] membuat model penilaian kuantitatif untuk menilai unjuk kerja sistem ERP.

IT Balanced Scorecard (IT BSC) lebih lanjut dikembangkan oleh Van Grembergen dan Van Bruggen [9], Van Grembergen dan Timmerman [10], serta Van Grembergen [11]. Perbedaan antara Balanced Scorecard dengan IT Balanced Scorecard ditunjukkan pada gambar 3.

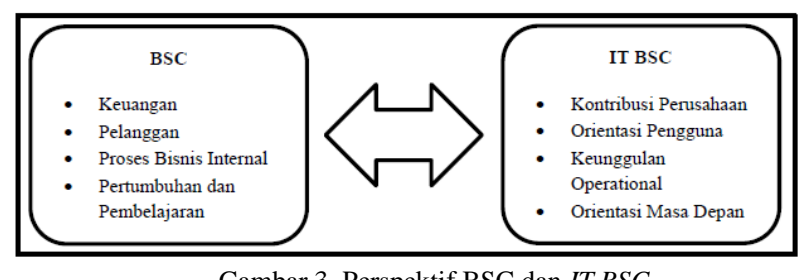

Gambar 3. Perspektif BSC dan IT BSC

Pada gambar 4 ditunjukkan IT BSC generik. Perspektif User Orientation menunjukkan evaluasi pengguna terhadap 
TI. Perspektif Operational Excellence menunjukkan proses TI yang digunakan untuk membangun dan mendukung aplikasi. Perspektif Future orientation menunjukkan sumber daya manusia dan teknologi yang dibutuhkan oleh TI untuk menghasilkan layanannya. Perspektif Business Contribution menunjukkan nilai bisnis yang dihasilkan dari investasi TI.

Metode IT BSC selain dapat digunakan untuk mengukur manfaat penerapan TI juga dapat digunakan untuk menilai investasi suatu proyek TI dan mengukur unjuk kerja suatu sistem TI. Milis dan Mercken [12] menyarankan untuk menggunakan proses evaluasi berlapis yang diturunkan dari Balanced Scorecard untuk menilai proyek investasi TI. Sardjono dan Pujadi [13] melakukan pengukuran unjuk kerja sistem Managed File Transfer di perbankan dengan IT BSC.

\begin{tabular}{|c|c|}
\hline USER ORIENTATION & BUSINESS CONTRIBUTION \\
\hline $\begin{array}{l}\text { Perspective question } \\
\text { How do users view the IT department? } \\
\text { Mission } \\
\text { To be the preferred supplier of information systems. } \\
\text { Objectives } \\
\text { Preferred supplier of applications } \\
\text { - Preferred supplier of operations } \\
\text { - Partnership with users } \\
\text { User satisfaction }\end{array}$ & $\begin{array}{l}\text { Perspective question } \\
\text { How does management view the IT department? } \\
\text { Mission } \\
\text { To obtain a reasonable business contribution from IT. } \\
\text { Objectives } \\
\text { Control of IT expenses } \\
\text { - Business value of IT projects } \\
\text { Provision of new business capabilities }\end{array}$ \\
\hline OPERATIONAL EXCELLENCE & FUTURE ORIENTATION \\
\hline $\begin{array}{l}\text { Perspective question } \\
\text { How effective and efficient are the IT processes? } \\
\text { Mission } \\
\text { To deliver effective and efficient IT systems and services. } \\
\text { Objectives } \\
\text { - Efficient and effective development efforts } \\
\text { - Efficient and effective operations }\end{array}$ & $\begin{array}{l}\text { Perspective question } \\
\text { How well is IT positioned to meet future needs? } \\
\text { Mission } \\
\text { To develop opportunities to answer future challenges. } \\
\text { Objectives } \\
\text { - Training and education of IT staff } \\
\text { - } \quad \text { Resertise of IT staff } \\
\text { - Age of application portfolio }\end{array}$ \\
\hline
\end{tabular}

\section{Metodologi Penelitian}

Tahap penelitian yang dilakukan meliputi tahap pengumpulan data, analisis data, dan penarikan kesimpulan. Proses pengumpulan data dilakukan dengan teknik kuesioner, wawancara, dan observasi langsung. Kuesioner disebarkan kepada pihak-pihak yang menggunakan Sistem Informasi PMB yaitu staf Kantor Admisi dan Akademik (KAA), koordinator bagian Instrumen Tes dan Evaluasi, staf Kantor Sistem Informasi, student staff KAA, calon mahasiswa, dekanat tiap fakultas, serta wakil rektor 1, 2, serta 3. Kegiatan wawancara dilakukan untuk memperkuat data yang didapatkan dari kuesioner. Proses observasi dilakukan dengan mengamati dan mencoba menggunakan Sistem Informasi PMB. Praktek menggunakan sistem ini dilakukan untuk mendapatkan gambaran pengalaman pengguna saat menggunakan sistem sekaligus menemukan permasalahannya.

Pada tahap analisis dilakukan beberapa kegiatan yaitu pembuatan peta strategi, mendefinisikan kinerja perspektif, mengukur kinerja perspektif, dan menyusun inisiatif. Pembuatan peta strategi dilakukan untuk mengetahui strategi yang dapat dilakukan untuk mencapai visi yang telah diturunkan kedalam tiap perspektif. Dalam proses mendefinisikan kinerja perspektif, ditentukan Critical Success Factor (CSF) tiap perspektif sebagai ukuran keberhasilan aktivitas untuk mencapai visi. CSF dibutuhkan untuk mengetahui apakah manfaat dari sistem benar-benar telah dirasakan atau belum. Pada pengukuran kinerja perspektif, ditetapkan alat ukur untuk mengukur ketercapaian CSF. Proses terakhir adalah menyusun inisiatif yang dilakukan untuk menentukan inisiatif apa yang bisa diambil untuk meningkatkan tingkat ketercapaian CSF di masa yang akan datang.

\section{HASIL DAN PEMBAHASAN}

\section{A. Pembuatan Peta Strategi (Strategic Map)}

Pembuatan peta strategi dimulai dengan mendefinisikan visi organisasi yang dimiliki. Visi tersebut selanjutnya diturunkan ke dalam visi masing - masing perspektif dari IT BSC yang meliputi perspektif Customer Orientation, Corporate Contribution, Operational Excellence, dan Future orientation. Selanjutnya ditetapkan strategi masing-masing perspektif. Disini visi organisasi yang digunakan adalah visi dari Kantor Admisi dan Akademik (KAA) yang memang bertanggung jawab untuk proses penerimaan mahasiswa baru. Peta strategi KAA dapat dilihat pada Gambar 5.

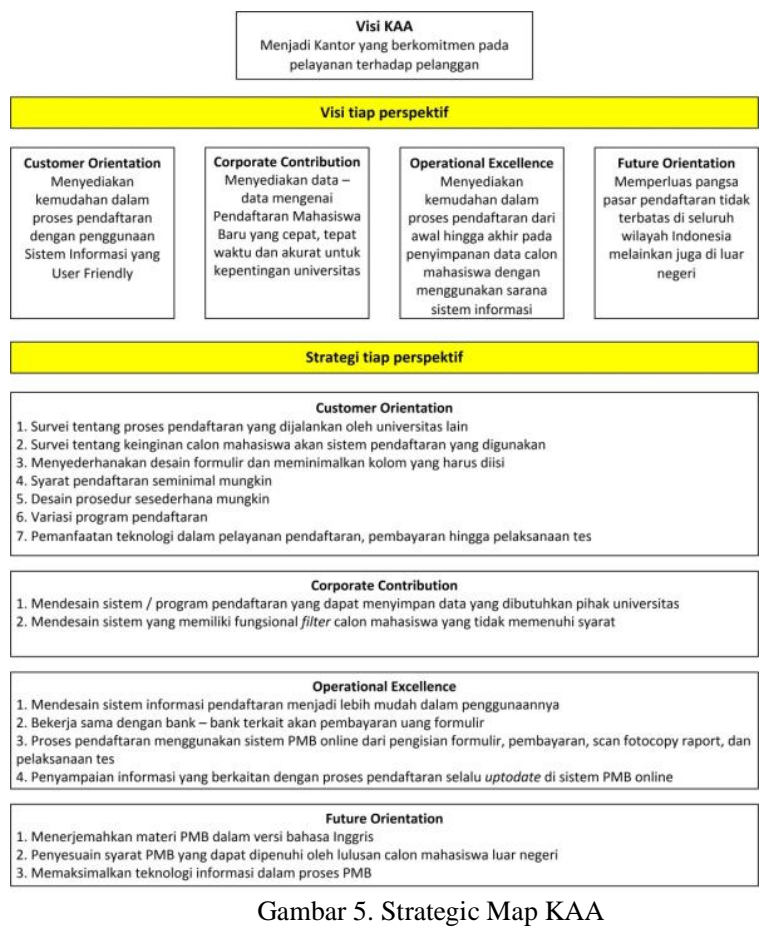

Pada Gambar 5 diatas ditunjukan bahwa visi dari setiap perspektif mendukung visi utama KAA. Visi dan strategi setiap perspektif akan digunakan sebagai pedoman untuk mengukur keberhasilan penerapan sistem informasi PMB.

\section{B. Mendefinisikan Kinerja Perspektif}

Dalam tahapan ini akan didefinisikan kinerja dari masing - masing perspektif. Dalam setiap perspektif akan ditetapkan tujuan - tujuan yang ini dicapai. Untuk setiap tujuan strategis akan ditetapkan paling sedikit satu pengukuran kinerja. Untuk dapat menghasilkan pengukuran kinerja yang bermanfaat maka organisasi harus dapat mengidentifikasikan hasil yang diinginkan dan proses yang dilakukan untuk mencapai hasil tersebut. Oleh sebab itu 
dalam mendefinisikan kinerja tiap perspektif harus ditetapkan Critical Success Factor (CSF)-nya. CSF dapat menjadi ukuran kesuksesan yang diharapkan dari penggunaan sistem informasi PMB. Gambar 6 menggambarkan CSF dari masing-masing perspektif beserta alat ukur yang digunakan untuk mengukur pencapaian CSF.

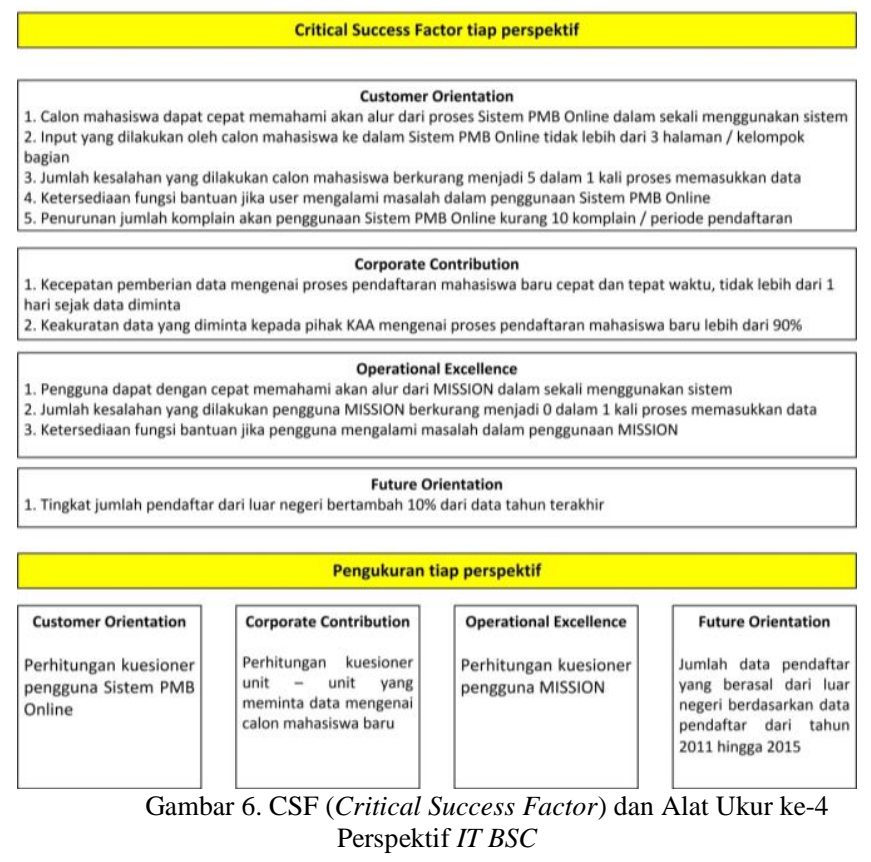

Dari perspektif Customer Orientation, sistem dianggap sukses jika beberapa CSF berikut tercapai: (1) Calon mahasiswa dapat dengan cepat memahami alur proses sistem PMB Online pada saat pertama kali menggunakan sistem, (2) Data-data yang dimasukkan oleh calon mahasiswa ke dalam sistem PMB Online tidak lebih dari 3 halaman / kelompok bagian, (3) Maksimal jumlah kesalahan input data yang dilakukan calon mahasiswa adalah 5 kali, (4) Tersedianya fungsi bantuan jika pengguna mengalami masalah dalam menggunakan sistem, dan (5) Jumlah keluhan pelanggan akan penggunaan sistem PMB online maksimal 10 keluhan per periode pendaftaran.

Dari perspektif Corporate Contribution, sistem dianggap sukses jika dua CSF berikut tercapai: (1) Waktu respon terhadap permintaan data-data PMB dari stakeholder tidak lebih dari satu hari sejak diminta, dan (2) Keakuratan data PMB lebih dari 90\%. Dari perspektif Operational Excellence, sistem dianggap sukses jika tiga CSF berikut tercapai: (1) Pengguna sistem MISSION dapat dengan cepat memahami alur sistem pada saat pertama kali menggunakan sistem, (2) Tidak ada lagi kesalahan pemasukan data pada sistem MISSION, dan (3) Tersedianya fungsi bantuan jika pengguna mengalami masalah saat menggunakan sistem MISSION. Dari perspektif terakhir yaitu Future orientation, sistem akan dianggap sukses jika terdapat peningkatan jumlah pendaftar dari luar negeri sebanyak $10 \%$ dari data tahun terakhir.

Dari identifikasi CSF-CSF tersebut ditentukan alat ukur yang dapat digunakan untuk mengukur ketercapaian CSF. Untuk perspektif Customer Orientation alat ukur yang digunakan adalah kuesioner yang diberikan pada pengguna sistem PMB Online (calon mahasiswa). Kuesioner disebarkan secara online lewat internet. Alat ukur yang digunakan untuk mengukur ketercapaian CSF pada perspektif Corporate Contribution adalah kuesioner yang diberikan kepada unit-unit di UAJY yang membutuhkan data-data PMB, termasuk fakultas-fakultas. Untuk perspektif Operational Excellence, alat ukur yang digunakan untuk mengukur ketercapaian CSF adalah kuesioner yang diberikan kepada semua pihak di UAJY yang menggunakan sistem MISSION. Alat ukur yang digunakan untuk mengukur ketercapaian CSF dari perspektif Future orientation adalah data-data jumlah pendaftar dari tahun 2011 sampai 2015.

\section{Mengukur Kinerja Perspektif}

Pada tahap ini akan diukur kinerja setiap perspektif menggunakan alat-alat ukur yang sudah. Pengukuran kinerja ini memiliki tujuan untuk mengetahui tingkat ketercapaian CSF yang ditetapkan sehubungan dengan penggunaan sistem informasi PMB. Pengukuran dari perspektif Customer Orientation dan Operational Excellence menggunakan perhitungan hasil kuesioner yang telah disebarkan ke pengguna sistem, baik MISSION maupun Sistem PMB Online. Untuk perspektif Corporate Contribution dan Future Orientation menggunakan sumber data dari KAA mulai tahun 2011 hingga tahun 2015. Pengambilan data melalui penyebaran kuesioner dilakukan kepada 250 calon mahasiswa, 40 student staff dan 5 staff KAA, dekan tiap fakultas dan wakil rektor 1, 2, dan 3. Pertanyaan yang diajukan lewat kuesioner berkaitan dengan tingkat ketercapaian CSF masing-masing perspektif.

Hasil dari kinerja perspektif Customer Orientation dirangkum pada tabel 1 .

TABEL I

RANGKUMAN PENILAIAN CSF PERSPEKTIF CUSTOMER ORIENTATION

\begin{tabular}{|l|l|l|}
\hline NO & \multicolumn{1}{|c|}{ Critical Success Factor } & Hasil \\
\hline 1 & $\begin{array}{l}\text { Calon mahasiswa dapat cepat } \\
\text { memahami akan alur dari proses } \\
\text { Sistem PMB Online dalam sekali } \\
\text { menggunakan sistem }\end{array}$ & Tercapai \\
\hline 2 & $\begin{array}{l}\text { Input yang dilakukan oleh calon } \\
\text { mahasiswa kedalam Sistem PMB } \\
\text { Online tidak lebih dari 3 halaman / } \\
\text { kelompok bagian }\end{array}$ & $\begin{array}{l}\text { Tidak } \\
\text { Tercapai }\end{array}$ \\
\hline 3 & $\begin{array}{l}\text { Ketersediaan fungsi bantuan jika } \\
\text { user mengalami masalah dalam } \\
\text { penggunaan Sistem PMB Online }\end{array}$ & $\begin{array}{l}\text { Tidak } \\
\text { Tercapai }\end{array}$ \\
\hline 4 & $\begin{array}{l}\text { Penurunan jumlah keluhan akan } \\
\text { penggunaan Sistem PMB Online } \\
\text { kurang 10 keluhan / periode } \\
\text { pendaftaran }\end{array}$ & $\begin{array}{l}\text { Tidak } \\
\text { Tercapai }\end{array}$ \\
\hline
\end{tabular}

Pada Tabel 1 diatas dapat dilihat bahwa untuk penilaian pada perspektif Customer Orientation, dari 5 CSF yang telah ditentukan, 2 dikatakan sudah tercapai dan 3 tidak tercapai. 


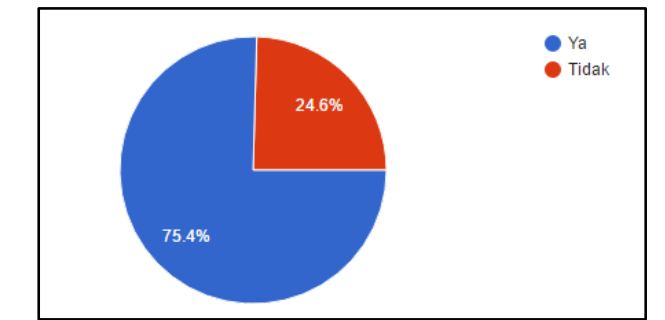

Gambar 7. Hasil Kuesioner Pertanyaan CSF pertama pada Perspektif Customer Orientation

Untuk CSF yang pertama sebanyak $75.4 \%$ responden mengatakan bahwa mereka langsung mengetahui maksud dari alur penggunaan sistem saat pertama kali menggunakan tanpa meminta bantuan dengan bertanya pada pihak UAJY (gambar 7). Sedangkan $24.6 \%$ responden memilih tidak, yang berarti mereka tidak mengetahui alur Sistem PMB Online pada saat mereka pertama kali mengakses dan membutuhkan beberapa kali pengaksesan agar mereka benar mengerti alur yang dimaksudkan. CSF ini dikatakan tercapai karena jumlah responden yang cepat memahami alur sistem PMB online jumlahnya lebih banyak. Untuk CSF yang kedua sebanyak $94.7 \%$ responden mengatakan bahwa formulir yang harus mereka isikan saat ini terlalu banyak yaitu 7 halaman (gambar 8).

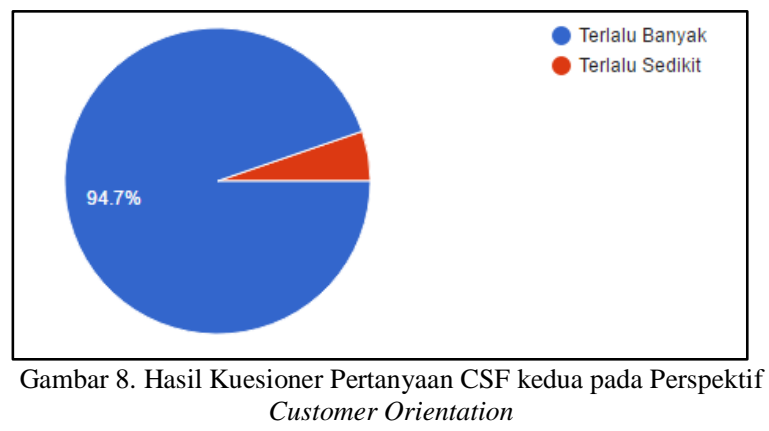

Di pertanyaan yang lain ditanyakan tentang banyaknya halaman pengisian formulir yang ideal. Hasilnya $75.4 \%$ responden menginginkan pengisian formulir sebanyak 3 sampai 5 halaman dan $22.8 \%$ responden memilih pengisian formulir yang ideal seharusnya tidak lebih dari 3 lembar. Sebagian besar responden mengatakan bahwa data - data yang penting untuk diisi oleh calon mahasiswa adalah data diri, data orang tua dan pilihan program studi. 3 halaman mengenai data - data tersebut dirasa cukup untuk pengisian formulir secara online, tanpa melihat / harus memasukkan nilai - nilai rapor. Berdasarkan data tersebut, maka CSF ini dapat dikatakan tidak tercapai, karena pada kenyataannya halaman yang harus diisi oleh calon mahasiswa adalah 7 halaman sedangkan CSF ini memiliki target isi formulir tidak lebih dari 3 halaman.

Untuk CSF ketiga sebanyak $94.7 \%$ responden mengatakan bahwa diperlukan fungsi bantuan di Sistem PMB Online. Sedangkan 5.3\% responden mengatakan tidak perlu adanya fungsi bantuan di dalam sistem. Fungsi bantuan yang diinginkan responden adalah live chat, dimana mereka dapat langsung bertanya jika mengalami kesalahan, tanpa harus menunggu petugas yang melayani. Berdasarkan data tersebut, CSF ini dikatakan tidak tercapai, karena fungsi bantuan yang tersedia saat ini di sistem PMB Online masih kurang untuk cepat dan tanggap untuk membantu permasalahan yang dialami oleh calon mahasiswa saat menggunakan sistem.

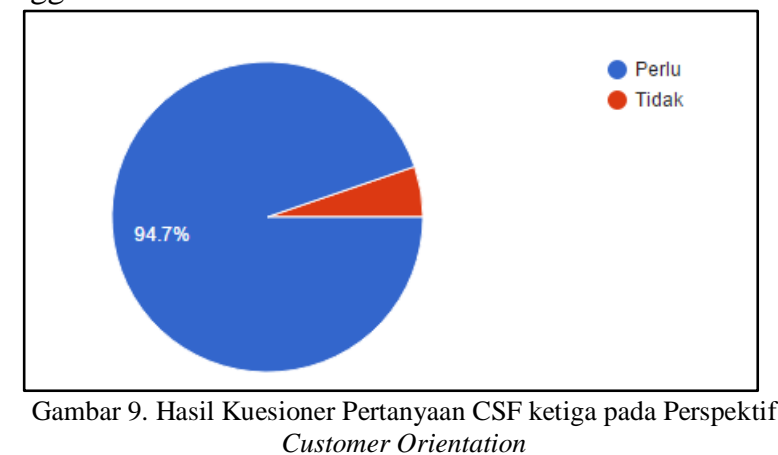

Untuk CSF keempat sebanyak sebanyak $62.5 \%$ responden mengatakan pernah menerima keluhan dan $37.5 \%$ atau 12 responden belum pernah menerima keluhan (gambar 9). Keluhan yang mereka terima antara lain Sistem PMB Online dan server yang sering error, gagal menyimpan data dan mengisi data formulir, data di beberapa formulir yang tidak terisi serta data - data yang tidak ada di basisdata. Aktivasi manual untuk program Reguler online juga menjadi kendala dan sering kali bagian pendaftaran menerima keluhan tentang hal itu, menjadikan proses pendaftaran bertambah lama. Jumlah keluhan mahasiswa per periode lebih dari 10 keluhan, sehingga CSF dapat dikatakan tidak tercapai.

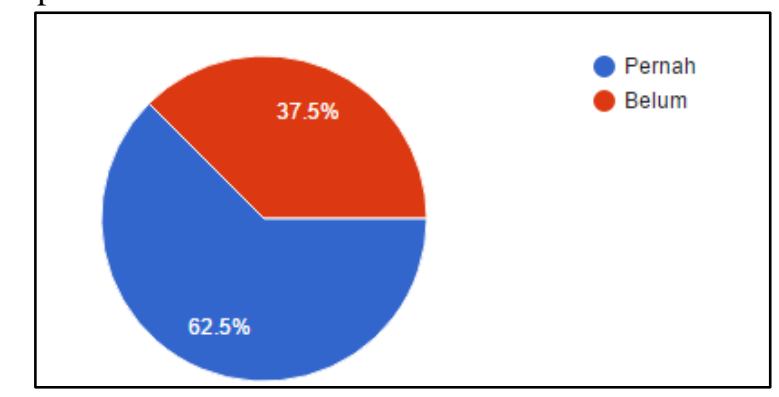

Gambar 9. Hasil Kuesioner Pertanyaan CSF keempat pada Perspektif Customer Orientation

Dari data-data diatas dapat ditarik kesimpulan bahwa dari perspektif Customer Orientation, Sistem PMB Online belum dapat dirasakan manfaat sepenuhnya oleh pengguna.

Tabel 2 menunjukkan hasil pengukuran kinerja pada perspektif Corporate Contribution. Hasil ini didapatkan dari pengisian kuesioner oleh wakil rektor 1 , wakil rektor 2, dan wakil rektor 3, dekanat tiap fakultas, serta staf dan koordinator instrumen tes dan evaluasi.

TABEL II

HASIL PENILAIAN CSF PERSPEKTIF CORPORATE CONTRIBUTION

\begin{tabular}{|l|lr|c|}
\hline $\begin{array}{l}\text { N } \\
\text { o. }\end{array}$ & \multicolumn{2}{|c|}{ Critical Success Factor } & Hasil \\
\hline 1 & $\begin{array}{l}\text { Kecepatan pemberian data } \\
\text { mengenai }\end{array}$ proses pendaftaran & Tercapai \\
\hline
\end{tabular}




\begin{tabular}{|c|l|c|}
\hline $\begin{array}{l}\text { N } \\
\text { o. }\end{array}$ & \multicolumn{1}{|c|}{ Critical Success Factor } & Hasil \\
\hline & $\begin{array}{l}\text { mahasiswa baru cepat dan tepat } \\
\text { waktu, tidak lebih dari 1 hari sejak } \\
\text { data diminta }\end{array}$ & \\
\hline 2 & $\begin{array}{l}\text { Keakuratan data yang diminta } \\
\text { kepada pihak KAA mengenai proses } \\
\text { pendaftaran mahasiswa baru lebih } \\
\text { dari 90\% }\end{array}$ & Tercapai \\
\hline
\end{tabular}

Untuk CSF pertama sebanyak $75 \%$ responden mengatakan bahwa pemberian data dari pihak KAA dapat dilakukan secara cepat dan tepat waktu. Data yang dibutuhkan dapat diberikan tidak lebih dari satu hari. Untuk CSF kedua 75\% responden (gambar 10) mengatakan bahwa data yang diberikan oleh KAA keakuratannya lebih dari $90 \%$ sesuai dengan permintaan dari para responden. Dari datadata tersebut dapat dilihat bahwa pada perspektif Corporate Contribution semua CSF dinyatakan telah tercapai. Hal ini bermakna Sistem Informasi PMB telah dapat dirasakan kontribusinya untuk perkembangan universitas.

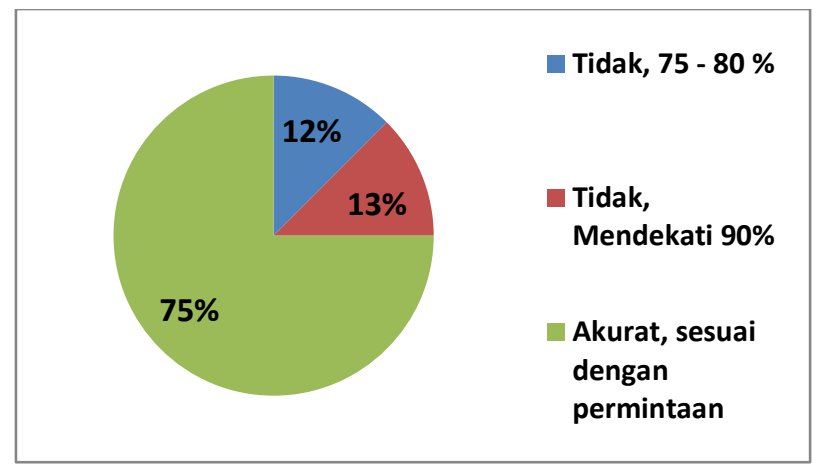

Gambar 10. Hasil Kuesioner Pertanyaan CSF pertama pada Perspektif Corporate Contribution

Untuk pengukuran pada perspektif Operational Excellence dilakukan berdasarkan hasil kuesioner yang disebarkan kepada semua pengguna yang menggunakan Sistem Informasi MISSION. Hasil pengukuran kinerja dapat dilihat pada Tabel 3 .

TABEL III

HASIL PENILAIAN CSF PERSPEKTIF OPERATIONAL EXCELLENCE

\begin{tabular}{|l|l|l|}
\hline No & \multicolumn{1}{|c|}{ Critical Success Factor } & Hasil \\
\hline 1 & $\begin{array}{l}\text { Pengguna dapat dengan cepat } \\
\text { memahami akan alur dari MISSION } \\
\text { dalam sekali menggunakan sistem }\end{array}$ & $\begin{array}{l}\text { Tidak } \\
\text { Tercapai }\end{array}$ \\
\hline 2 & $\begin{array}{l}\text { Jumlah kesalahan yang dilakukan } \\
\text { pengguna MISSION berkurang } \\
\text { menjadi 0 dalam 1 kali proses } \\
\text { memasukkan data }\end{array}$ & Tidak \\
Tercapai \\
\hline 3 & $\begin{array}{l}\text { Ketersediaan fungsi bantuan jika } \\
\text { pengguna mengalami masalah } \\
\text { dalam penggunaan MISSION }\end{array}$ & $\begin{array}{l}\text { Tidak } \\
\text { Tercapai }\end{array}$ \\
\hline
\end{tabular}

Untuk CSF pertama sebanyak $81.3 \%$ responden mengatakan tidak memahami kegunaan dari fungsi - fungsi yang ada di MISSION sedangkan $18.8 \%$ langsung mengetahui kegunaan dari sebagian besar fungsi yang ada di MISSION pada saat pertama kali menggunakan (gambar 11). Sistem informasi MISSION memiliki fungsi yang cukup kompleks sehingga membutuhkan waktu yang tidak sebentar untuk mempelajarinya. Menjawab pertanyaan yang berbeda, sebanyak $65.6 \%$ mengatakan dapat langsung memasukkan data calon mahasiswa kedalam sistem MISSION dalam 1 hingga 3 kali percobaan, 29\% memerlukan 4 hingga 5 kali percobaan dan $6.3 \%$ membutuhkan lebih dari 7 kali percobaan. Berdasarkan data tersebut, CSF ini dinyatakan tidak tercapai, karena diperlukan lebih dari 1 kali percobaan untuk dapat memahami dan menggunakan sistem MISSION.

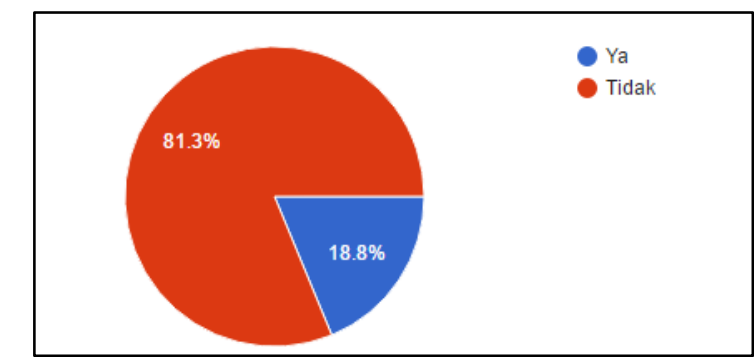

Gambar 11. Hasil Kuesioner Pertanyaan CSF pertama pada Perspektif Operational Excellence

Untuk CSF kedua sebanyak $84.4 \%$ responden mengatakan pernah mengalami kesalahan pada saat menggunakan sistem MISSION pada sekali login dan 15.6\% responden belum pernah melakukan kesalahan (gambar 12). Kesalahan yang sering dilakukan diantaranya salah pilihan periode, jalur pendaftaran, data diri calon mahasiswa, memasukan nomor pendaftaran, salah prosedur pendaftaran, dan salah memasukkan nilai untuk rapor. Lebih lanjut ditanyakan seberapa sering student staff melakukan kesalahan. Sebanyak $41.1 \%$ responden melakukan kesalahan sebanyak 1 kali, $37.9 \%$ responden melakukan kesalahan sebanyak 2 kali, dan $10.3 \%$ responden melakukan kesalahan 3 kali atau lebih. Berdasarkan data tersebut, CSF ini dapat dikatakan gagal, karena dalam sekali login pengguna sistem MISSION kerap kali melakukan kesalahan.

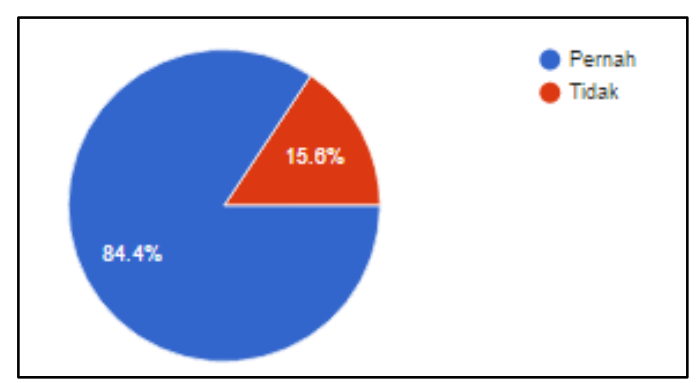

Gambar 12. Hasil Kuesioner Pertanyaan CSF kedua pada Perspektif Operational Excellence

Untuk CSF ketiga tentang ketersediaan fungsi bantuan jika pengguna mengalami masalah dalam penggunaan sistem MISSION, sebanyak $87.5 \%$ responden mengatakan perlu diadakannya fungsi bantuan yang ada di sistem MISSION, sedangan $12.5 \%$ responden mengatakan tidak perlu adanya fungsi bantuan tersebut (gambar 13). Berdasarkan data tersebut, CSF ini dapat dikatakan tidak tercapai, karena 
fungsi bantuan belum tersedia pada sistem MISSION saat ini, bantuan hanya dapat dengan cara menghubungi pihak Kantor Sistem Informasi UAJY. Dari tabel 3 dapat dilihat bahwa hasil penilaian menunjukkan bahwa ke-CSF yang ditetapkan belum dapat dicapai dengan penggunaan sistem MISSION.

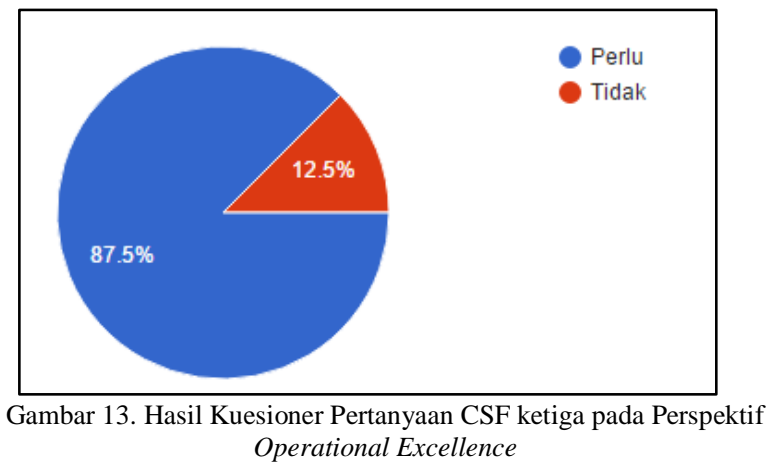

Pengukuran pada perspektif Future Orientation dilakukan berdasarkan data - data pendaftar calon mahasiswa yang dimiliki KAA dari tahun 2010 hingga tahun 2015 .

TABEL IV

JUMLAH PERSENTASE PENDAFTAR WNA TIAP TAHUN DARI 2011 HINGGA 2015

\begin{tabular}{|l|c|c|c|}
\hline TH & $\begin{array}{c}\text { Th } \\
\text { Sblmnya }\end{array}$ & $\begin{array}{c}\text { Th } \\
\text { Sekarang }\end{array}$ & $\begin{array}{l}\text { Prosentase } \\
\text { Selisih }\end{array}$ \\
\hline 2011 & 38 & 23 & $-39 \%$ \\
\hline 2012 & 23 & 37 & $60 \%$ \\
\hline 2013 & 37 & 49 & $32 \%$ \\
\hline 2014 & 49 & 66 & $30 \%$ \\
\hline 2015 & 66 & 42 & $-36 \%$ \\
\hline
\end{tabular}

Berdasarkan tabel 4 dapat dilihat bahwa jumlah pendaftar dari tahun 2011 hingga 2015 tidak selalu meningkat secara signifikan maupun konsisten. Tahun 2011 mengalami penurunan jumlah pendaftar WNA sebesar 39\% dari tahun sebelumnya, dan tahun 2015 mengalami penurunan sebesar $36 \%$. Selain tahun tersebut mengalami kenaikan sebesar $60 \%$ pada tahun 2012 , 32\% pada tahun 2013, dan 30\% pada tahun 2014. Data-data tersebut membuktikan bahwa Sistem PMB Online sebagai sistem yang berhubungan langsung dengan calon mahasiswa kurang begitu efektif untuk memikat calon mahasiwa yang berasal dari luar Indonesia. Beberapa pengguna sistem PMB Online menyarankan untuk membuat versi bahasa Inggrisnya, untuk mengakomodasi calon mahasiswa dari luar negeri yang belum dengan aktif menguasai bahasa Indonesia. Sebanyak $78.1 \%$ responden mengatakan bahwa diperlukan penjelasan PMB dalam bahasa Inggris untuk Sistem PMB Online, sedangkan $21.9 \%$ responden mengatakan tidak perlu (gambar 14). Hasil pengukuran dapat dilihat pada tabel 5.

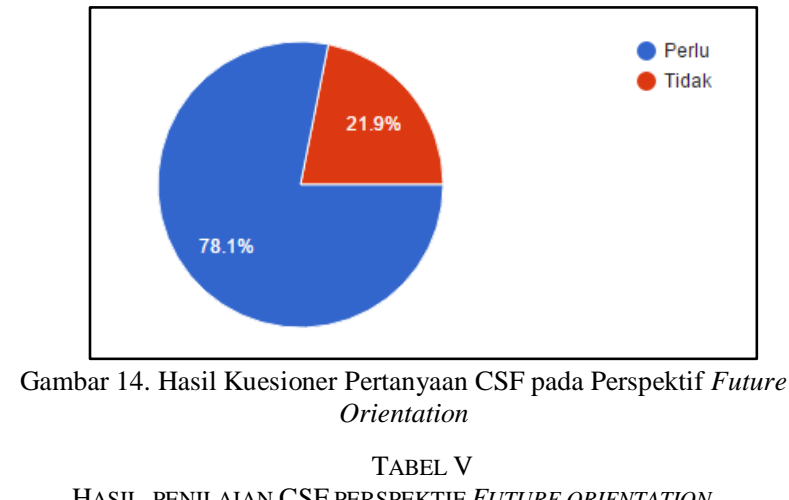

HASIL PENILAIAN CSF PERSPEKTIF FUTURE ORIENTATION

\begin{tabular}{|l|c|}
\hline \multicolumn{1}{|c|}{ Critical Success Factor } & Hasil \\
\hline $\begin{array}{l}\text { Tingkat jumlah pendaftar dari luar } \\
\text { negeri bertambah 10\% dari data tahun } \\
\text { terakhir }\end{array}$ & Tidak Tercapai \\
\hline
\end{tabular}

Dari tabel 5 diatas dapat dilihat bahwa pada perspektif Future Orientation kinerja CSF tidak tercapai.

\section{Menyusun Inisiatif}

Tahap menyusun inisiatif ini merupakan tahap pendefinisian rekomendasi inisiatif yang harus dilakukan supaya tujuan strategis dapat dicapai. Dari hasil pengukuran kinerja semua perspektif, inisiatif akan disusun berdasarkan CSF yang belum tercapai. Tabel 6, tabel 7, tabel 8, dan tabel 9 menunjukkan kaitan antara visi, CSF, hasil pengukuran dan inisiatif yang direkomendasikan pada masing-masing perspektif BSC.

TABEL VI

HuBUNGAN ANTARA VISI, CSF, HASIL PENGUKURAN DAN INISIATIF PADA PERSPEKTIF CUSTOMER ORIENTATION

\begin{tabular}{|c|c|c|c|}
\hline \multicolumn{4}{|c|}{ Perspektif: Customer Orientation } \\
\hline \multicolumn{4}{|c|}{$\begin{array}{l}\text { Visi: Menyediakan kemudahan dalam proses } \\
\text { pendaftaran dengan penggunaan Sistem Informasi yang } \\
\text { User Friendly }\end{array}$} \\
\hline No & $\begin{array}{l}\text { Critical } \\
\text { Success Factor } \\
\text { (CSF) }\end{array}$ & $\begin{array}{c}\text { Hasil } \\
\text { Pengukuran }\end{array}$ & Inisiatif \\
\hline 1 & \begin{tabular}{l}
\multicolumn{2}{c|}{ Calon } \\
mahasiswa \\
dapat cepat \\
memahami \\
akan alur dari \\
proses \\
PMBstem \\
dalam sekali \\
menggunakan \\
sistem
\end{tabular} & Tercapai- & - \\
\hline 2 & $\begin{array}{l}\quad \text { Input } \\
\text { yang } \\
\text { dilakukan } \\
\text { oleh calon } \\
\text { mahasiswa } \\
\text { kedalam }\end{array}$ & $\begin{array}{l}\text {-Tidak } \\
\text { Tercapai- }\end{array}$ & \begin{tabular}{l}
\multicolumn{2}{c}{ Calon } \\
mahasiswa \\
mengisi formulir \\
sebanyak \\
halaman, yakni \\
data diri, data
\end{tabular} \\
\hline
\end{tabular}




\begin{tabular}{|c|c|c|c|}
\hline \multicolumn{4}{|c|}{ Perspektif: Customer Orientation } \\
\hline \multicolumn{4}{|c|}{$\begin{array}{l}\text { Visi: Menyediakan kemudahan dalam proses } \\
\text { pendaftaran dengan penggunaan Sistem Informasi yang } \\
\text { User Friendly }\end{array}$} \\
\hline No & $\begin{array}{c}\text { Critical } \\
\text { Success Factor } \\
(\mathrm{CSF}) \\
\end{array}$ & $\begin{array}{c}\text { Hasil } \\
\text { Pengukuran }\end{array}$ & Inisiatif \\
\hline & $\begin{array}{lr}\text { Sistem } & \text { PMB } \\
\text { Online tidak } \\
\text { lebih dari } & 3 \\
\text { halaman } & / \\
\text { kelompok } & \\
\text { bagian } & \end{array}$ & & \begin{tabular}{l} 
orang tua dan \\
pilihan program \\
studi. \\
\multicolumn{1}{c}{ Data } \\
lengkapnya diisi \\
waktu calon \\
mahasiswa telah \\
dinyatakan \\
diterima, fungsi \\
melengkapi data \\
di Sistem PMB \\
Online
\end{tabular} \\
\hline 3 & $\begin{array}{l}\text { Ketersed } \\
\text { iaan fungsi } \\
\text { bantuan jika } \\
\text { user } \\
\text { mengalami } \\
\text { masalah } \\
\text { dalam } \\
\text { penggunaan } \\
\text { Sistem PMB } \\
\text { Online }\end{array}$ & $\begin{array}{l}\text {-Tidak } \\
\text { Tercapai- }\end{array}$ & \begin{tabular}{l}
\multicolumn{2}{c}{ Disediakan } \\
fungsi chatlive \\
yang dapat \\
mempermudah \\
penanganan \\
masalah yang \\
dialami oleh \\
calon mahasiswa \\
mengenai \\
pendaftaran, aktif \\
saat jam kerja \\
dan dapat \\
langsung \\
dilayani oleh \\
petugas yang \\
berkaitan
\end{tabular} \\
\hline 4 & 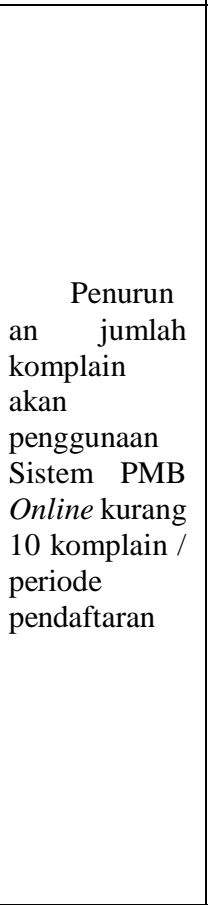 & Tercapai- & \begin{tabular}{lr}
\multicolumn{2}{c}{ Memperbai } \\
ki server agar \\
tidak terjadi \\
down saat \\
pengakses yang \\
begitu banyak \\
menyimpan data \\
mereka, serta \\
memberikan \\
fungsi \\
penambahan \\
alamat kepada \\
pihak KAA agar \\
pada saat daerah \\
dari calon \\
mahasiswa tidak \\
ada didalam \\
database dapat \\
dengan cepat \\
ditambahkan \\
oleh pihak KAA \\
tanpa harus \\
menunggu \\
menghubungi \\
KSI
\end{tabular} \\
\hline
\end{tabular}

Pada perspektif Customer Orientation inisiatif diberikan pada CSF-CSF yang belum tercapai, yaitu CSF 2 dan 3. CSF ke-2 menginginkan input data yang dilakukan calon mahasiswa tidak lebih dari tiga halaman. Inisiatif yang diusulkan adalah pada sistem PMB Future orientation formulir yang harus diisikan calon mahasiswa dibuat maksimal 3 halaman, yang terdiri dari data diri, data orang tua, dan data pilihan program studi. Untuk data-data lain dapat dilengkapi setelah calon mahasiswa melakukan tes dan dinyatakan diterima. Untuk memenuhi CSF yang ke-3, yaitu ketersediaan fungsi bantuan saat pengguna mengalami masalah diberikan inisiatif menyediakan fungsi live chat yang selalu siap melayani pertanyaan-pertanyaan dan keluhan pelanggan setiap saat. Dengan inisiatif ini permasalahan pengguna dapat ditangani dengan cepat.

TABEL VII

HUBUNGAN ANTARA VISI, CSF, HASIL PENGUKURAN DAN INISIATIF PADA PERSPEKTIF CORPORATE CONTRIBUTION

\begin{tabular}{|c|c|c|c|}
\hline \multicolumn{4}{|c|}{ Perspektif: Corporate Contribution } \\
\hline \multicolumn{4}{|c|}{$\begin{array}{l}\text { Visi: Menyediakan data - data mengenai Pendaftaran Mahasiswa } \\
\text { Baru yang cepat, tepat waktu dan akurat untuk kepentingan universitas }\end{array}$} \\
\hline No & $\begin{array}{c}\text { Critical } \\
\text { Success Factor } \\
(\mathrm{CSF})\end{array}$ & $\begin{array}{c}\text { Hasil } \\
\text { Pengukuran }\end{array}$ & Inisiatif \\
\hline 1 & $\begin{array}{l}\text { Kecepatan } \\
\text { pemberian data } \\
\text { mengenai } \\
\text { proses } \\
\text { pendaftaran } \\
\text { mahasiswa baru } \\
\text { cepat dan tepat } \\
\text { waktu, tidak } \\
\text { lebih dari } 1 \text { hari } \\
\text { sejak data } \\
\text { diminta }\end{array}$ & Tercapai- & - \\
\hline 2 & $\begin{array}{lr} & \text { Keakuratan } \\
\text { data yang } \\
\text { diminta kepada } \\
\text { pihak KAA } \\
\text { mengenai } \\
\text { proses } \\
\text { pendaftaran } \\
\text { mahasiswa baru } \\
\text { lebih dari } 90 \%\end{array}$ & Tercapai- & - \\
\hline 3 & $\begin{array}{l}\text { Pengguna } \\
\text { dapat dengan } \\
\text { cepat } \\
\text { memahami akan } \\
\text { alur dari } \\
\text { MISSION } \\
\text { dalam sekali } \\
\text { menggunakan } \\
\text { sistem }\end{array}$ & $\begin{array}{l}\text {-Tidak } \\
\text { Tercapai- }\end{array}$ & $\begin{array}{l}\text { Menyederhanakan } \\
\text { tampilan dan penyajian } \\
\text { fungsi-fungsi }\end{array}$ \\
\hline
\end{tabular}

Pada perspektif Corporate Contribution inisiatif diberikan pada CSF yang belum tercapai yaitu CSF ke-3. Selama ini pengguna masih merasa kesulitan dalam memahami alur sistem MISSION. Inisiatif yang diusulkan adalah dengan menyederhanakan tampilan dan penyajian fungsi-fungsi serta menyediakan fungsi bantuan yang dapat dengan cepat menjawab kesulitan yang dialami pengguna saat menggunakan sistem. Tampilan harus dibuat lebih ramah pengguna, sederhana, menarik, dan mudah untuk dipelajari. 
TABEL VIII

HUBUNGAN ANTARA VISI, CSF, HASIL PENGUKURAN DAN INISIATIF PADA PERSPEKTIF OPERATIONAL EXCELLENCE

\begin{tabular}{|c|l|l|l|}
\hline \multicolumn{3}{|c|}{ Perspektif: Operational Excellence } \\
\hline \multicolumn{2}{|c|}{ Visi: Menyediakan data - data mengenai Pendaftaran } \\
Mahasiswa Baru yang cepat, tepat waktu dan akurat untuk \\
kepentingan universitas
\end{tabular}

Pada perspektif Operational Excellence inisiatif diberikan pada semua CSF karena semuanya belum tercapai. Untuk mengurangi jumlah kesalahan yang dilakukan pengguna saat menggunakan sistem MISSION diusulkan inisiatif dengan menyederhanakan tampilan dan penyajian fungsi-fungsi serta mengoptimalkan dalam penggunaan kontrol-kontrol yang dapat meminimalkan input data (pengetikan) dari pengguna. Beberapa fungsi yang selama ini harus dicek secara manual yang dapat diubah menjadi otomatis.

TABEL IX

Hubungan ANTARA VISI, CSF, HASIL PENGUKURAN DAN INISIATIF PADA PERSPEKTIF FUTURE ORIENTATION

\begin{tabular}{|c|c|c|c|}
\hline \multicolumn{4}{|c|}{ Perspektif: Future orientation } \\
\hline \multicolumn{4}{|c|}{$\begin{array}{l}\text { Visi: Memperluas pangsa pasar pendaftaran tidak terbatas } \\
\text { di seluruh wilayah Indonesia melainkan juga di luar negeri }\end{array}$} \\
\hline No & $\begin{array}{c}\text { Critical } \\
\text { Success Factor } \\
\text { (CSF) }\end{array}$ & $\begin{array}{c}\text { Hasil } \\
\text { Pengukuran }\end{array}$ & Inisiatif \\
\hline 1 & $\begin{array}{l}\text { Tingkat jumlah } \\
\text { pendaftar dari luar } \\
\text { negeri bertambah } \\
10 \% \text { dari data tahun } \\
\text { terakhir }\end{array}$ & $\begin{array}{l}\text {-Tidak } \\
\text { Tercapai- }\end{array}$ & $\begin{array}{l}\text { Membuat } \\
\text { Sistem PMB } \\
\text { Online, } \\
\text { formulir dan } \\
\text { penjelasan } \\
\text { tentang PMB } \\
\text { dalam versi }\end{array}$ \\
\hline
\end{tabular}

\begin{tabular}{|l|l|l|}
\hline & & bahasa \\
inggris. Test \\
online \\
disediakan \\
dalam bahasa \\
Indonesia.
\end{tabular}

Pada perspektif Future orientation ini inisiatif yang diusulkan bagi CSF adalah penyediaan fasilitas formulir dan penjelasan tentang penerimaan mahasiswa dalam bahasa Inggris sehingga calon mahasiswa dari luar negeri tidak perlu langsung datang ke kampus UAJY untuk mendapatkan informasi dan melakukan pendaftaran. Tes online yang selama ini dijalankan masih menggunakan bahasa Indonesia sehingga perlu dibuat tes online dalam bahasa Inggris yang dapat digunakan oleh calon mahasiswa asing.

\section{KESIMPULAN}

Berdasarkan hasil pengukuran kinerja pada proses pendaftaran mahasiswa baru dengan Sistem Informasi PMB UAJY menggunakan IT Balanced Scorecard dapat ditarik kesimpulan bahwa manfaat dari penggunaan Sistem Informasi PMB (dalam hal ini sistem PMB Online dan sistem MISSION) belum dapat dirasakan sepenuhnya untuk mendukung visi organisasi. Hal ini tampak dari keempat perspektif yang diukur kinerjanya, hanya ada satu perspektif yaitu Corporate Contribution yang terbukti dapat mendukung pencapaian tujuan organisasi dengan tercapainya Critical Success Factor yang dikehendaki. Pengukuran kinerja pada ketiga perspektif yang lain yaitu Customer Orientation, Operational Excellence dan Future orientation menunjukkan bahwa penggunaan Sistem Informasi PMB belum dapat dirasakan manfaat sepenuhnya untuk pencapaian tujuan organisasi. Dari ketiga perspektif yang masih lemah tersebut direkomendasikan inisiatif yang dapat diambil oleh UAJY untuk perbaikan sistem MISSION dan sistem PMB online.

\section{DAFTAR PUSTAKA}

[1] R. S. Kaplan and P. D. Norton, The Balanced Scorecard: Translating Strategy into Action, Boston, MA.: Harvard Business School Press, 1996.

[2] F. Rabbani et al., "Designing a Balanced Scorecard for a Tertiary Care Hospital in Pakistan: a Modified Delphi Group Exercise," International Journal of Health Planning and Management, vol. 25, no. 1, pp. 74-90, 2010.

[3] J. Michalska, "The Usage of The Balanced Scorecard for The Estimation of The Enterprise's Effectiveness," Journal of Materials Processing Technology, Vols. 162-163, pp. 751-758, 2005.

[4] C. Gold, "Total Quality Management in Information Services - IS Measures: A Balancing Act," Ernst and 
Young Center for Information Technology and Strategy, Boston, 1992.

[5] L. Willcocks, Infomation Management: The Evaluation of Information Systems Investments, London: Chapman and Hall, 1995.

[6] A. Asosheh et al., "An ERP System Performance Assessment Model Development based on The Balanced Scorecard Approach," Expert Systems with Applications, vol. 37, no. 8, pp. 5931-5938, 2010.

[7] D. Chand et al., "A Balanced Scorecard based Framework for Assessing the Strategic Impacts of ERP Systems," Computers in Industry, vol. 56, no. 6 , pp. 558-572, 2005.

[8] S.-I. Chang et al, "An ERP System Performance Assessment Model Development based on The Balanced Scorecard Approach," Information System Frontiers, vol. 13, no. 3, pp. 429-450, 2011.

[9] W. Van Grembergen and R. Van Bruggen, "Measuring and Improving Corporate Information Technology through The Balanced Scorecard Technique," in The Fourth European Conference on The Evaluation of Information Technology, Delft, October 1997.

[10] W. Van Grembergen and D. Timmerman, "Monitoring the IT Process through the Balanced Scorecard," in 9th Information Resources Management International Conference, Boston, May 1998.

[11] W. Van Grembergen, "The Balanced Scorecard and IT Governance," Information Systems Control Journal, vol. 2, pp. 40-43, 2000.

[12] K. Milis and R. Mercken, "The Use of The Balanced Scorecard for The Evaluation of Information and Communication Technology Projects," International Journal of Project Management, vol. 22, pp. 87--97, 2004.

[13] W. Sardjono and T. Pujadi, "Performance Evaluation of Systems Managed File Transfer in Banking Industry Using IT Balanced Scorecard," in The International Conference on Information

Management and Technology, Bandung, 2016. 